Papers and Proceedings of the Royal Society of Tasmania, Volume 116, 1982

(ms. received 30.1 .1981 )

PALAEOENVIRONMENT OF THE DARLINGTON LIMESTONE (EARLY PERMIAN), TASMANIA

by Kenneth G. Bri11, Jnr

Saint Louis University, St Louis, Missouri, U.S.A.

with three text-figures, two tables and one plate

ABSTRACT

BRILL, K.G., 1982 ( 31 viii): Palaeoenvironment of the Darlington Limestone (Early Permian),

Tasmania. Pap. Proc. R. Soc. Tasm., 116: 67-84.

https://doi.org/10.26749/rstpp.116.67 ISSN 0080-4703. St LouisUniversity, St Louis, Missouri, U.S.A.

The Early Permian Darlington Limestone in the Tasmania Basin consists of fossiliferous mudstone, siltstone and impure limestone. It was deposited in a somewhat restricted basin with uplands on the northeast and east, the northwest, and probably the southwest.

Icebergs from glaciers on the uplands or sea-ice may have transported erratic lonestones into the basin. Cold, low sainity water is indicated by a foramol fauna which contained many individuals but relatively tew genera and which is rich in foraminifera, bryozoans, spiriferids, and pelecypods.

Hydraulic energy was generally low. Little sorting and few sedimentary structures were observed. Evidence of current action is mainly on the periphery of the basin and suggests currents from the southwest. Such evidence is mostly the orientation of fossils. Islands such as the Beaconsfield-Frankford island, and shallows probably impeded current action in the basin.

\title{
I NTROUCTION
}

The Darlington Limestone ("Eurydesma" Limestone of authors) was named by Banks (1957) for exposures at Fossil Cliffs, north of Darlington on Maria Island. It was assigned to the lower unit of the Golden Valley Group (Wells 1957). The Golden Valley Groups is a unit of the Parmeener Super-Group (Banks 1973).

The Darlington Limestone is a facies of the Golden Valley Group in southern Tasmania and of the upper part of the Masseys Creek Group in northern Tasmania. Exposures of the formation are scattered over much of the State except for the northeast, northwest and southwest (Banks 1962, fig.30d). Its thickest and best development is at Fossil Cliffs on Maria Island. To the west and north of this locality it consists of thin beds or lenses of impure limestone in a thicker sequence of clastic strata.

The limestone is unusual in that it contains numerous randomly scattered clastic fragments, the most notable being pebbles and boulders of crystalline and sedimentary rocks, herein referred to as lonestones. Except in a few places, the lonestoncs seem not to be confined to particular bands. Many of these are presumed to be rafted fragments, dropped from icebergs or pack ice. Sand and silt-size terrigenous debris was probably derived from floating ice but some of the finest debris may be of aeolian origin.

Summary faunal lists are given in Banks (1962) and in Clarke and Banks (1975). The principal elements of the fauna are bryozoans, molluscs and spiriferids. The diversity of the fauna is not great but the number of individuals of a particular species is commonly large (Clarke and Banks 1975). Based on faunal zonation in eastern Australia this fauna has been assigned to the Middle Tamarian faunizone 2 (Clarke and Farmer 1976). Although this faunizone is associated with the limestone, it also embraces clastic strata, which northwest, west and southwest of Maria Island, both underlie and overlic the limestone. 
This study was undertaken by the writer during the latter part of 1978 while a visitor at the Geology Department of the University of Tasmania. The writer is most grateful to Professor 0.H. Green for generously providing use of the facilities of the Geology Department and funds foi laboratory work. The writer is deeply indebted to Dr Maxwell R. Banks of the Geology Department for suggesting the problem and for his many kindnesses, as well as for his help and encouragement as the work progressed. Thanks are due also to Mr M.J. Clarke of the Geological Survey of Tasmania for his assistance and valuable discussions in the field on Maria Island. The responsibility, however, for opinions expressed in this paper belongs to the writer alone. Dr Alastair Mckee of the University of Tasmania made the SEM photomicrographs, and Wendy Spencer prepared the in soluble residues. Landowners and many others aided the writer in many ways. To all he is grateful.

\section{STRAT IGRAPHY}

Maria Island

The type section of the Darlington Limestone (Banks 1957) is 1ocated at the north end of Maria Island. Here the formation is about $16 \mathrm{~m}$ thick and overlies the conglomeratic Erratic zone. The writer measured two detailed stratigraphic sections about $300 \mathrm{~m}$ apart at opposite ends of the Fossil Cliffs exposure. The eastern section, herein called the East Fossil Cliffs (EFC) differs somewhat from the western section called the West Darlington (WD). The latter contains more lonestones.

During deposition of the Darlington Limestone the shore lay on the east side of Maria Island, about $5 \mathrm{~km}$ east of the present Fossil Cliffs (Banks 1962). The underlying Middle Palaeozoic Mathinna sandstone and quartzite and Devonian granite seems to have provided many of the detrital fragments which are present in the Darlington Limestone. Lonestones of yellow siltstone and fine-grained quartzitic sandstone are present in the upper parts of both sections. These fragments appear to have been derived from the Mathinna Formation. Granite fragments are also present, but seem to be fewer in number than might be expected so close to the source. However, boulders of granite (and phyllite) $0.33 \mathrm{~m}$ in long dimension occur in the lower metre of the Fossil Cliffs section. Lonestones are of various types of metamorphic rocks. One boulder of schist is $0.5 \times 0.5 \times 0.4 \mathrm{~m}$ (Banks 1962). The exact source of many of these metamorphic rocks has not been determined but many of them may have originated in western Tasmania (Banks 1962).

As may be seen in figure 2, the distribution of lonestones is not uniform latera11y between the two sections, nor is there a consistent vertical pattern. This further suggests that the lonestones are erratics.

In the section of the Darlington Limestone at Fossil Cliffs, Banks (1957) recognized 11 cycles which consist of "an alternation of Eurydesma calcirudite and bryozoal siltstone near the base, and Eurydesma calcirudite and spiriferid calcirudite higher up". He suggested that the spiriferid calcirudite member of the cycle replaces the bryozoal siltstone member towards the top and attributed (1962) this change in sedimentation to a shallowing of the sea.

In the bryozoal siltstone, lonestones are rare and where present are small. Fenestrate bryozoans commonly delineate the bedding planes, but in a few places cross the planes at an angle. Small ramose Stenopora colonies are common and a few seem to be in growth position, especially near the tops of the beds. The fact that modern ramose bryozoans live in deep quiet water (Wass et al. 1970) may indicate a similar environment for the Maria Island siltstone. Some broad platy colonies of Stenopora johnstoni also occur.

Eurydesma calcirudites contain not only numerous Eurydesma but also Deztopeeten, spiriferids and Stenopora. An unusual phase of this type of calcirudite is coquinite. In each of the two sections there are three beds of coquinite which contain unusually large numbers of valves of Eurydesma most of which are disarticulated. More shells and shel1 fragments than matrix are present and the bedding is generally obscure. The basal 


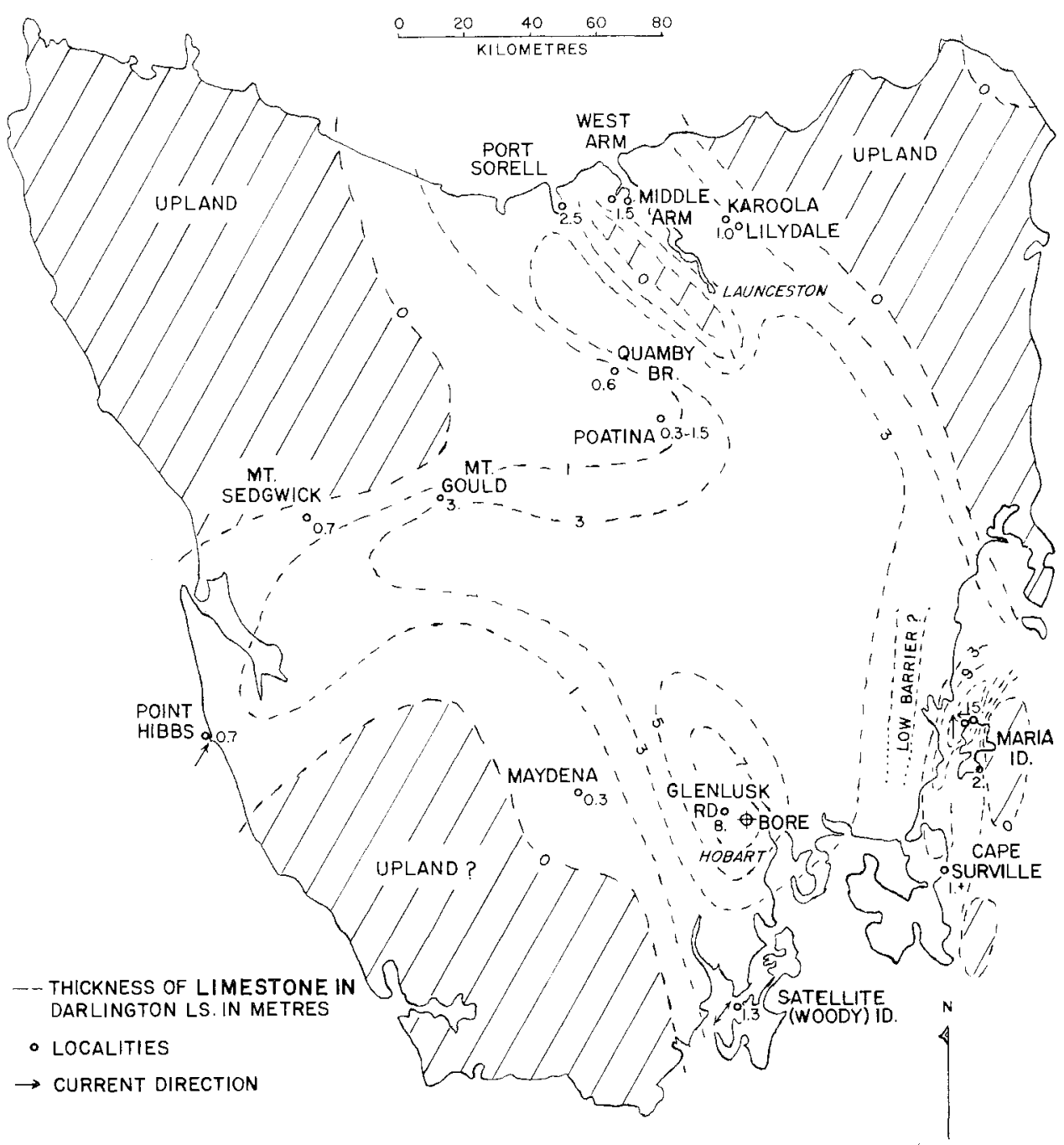

FIC. 1- Isopachous map of limestone in Darlington Limestone.

coquinite (EFC-2 and WD-2 and 3) seems to correlate between sections and EFC 18 correlates with WD-17. The other coquinites appear to be lenticular and do not extend from one section to the other.

Two methods were used on the outcrop to determine the percentage and orientation of fossils and lonestones. On the vertical face the number and orientation were noted on lines parallel to the bedding using the stretched-line method (Johnson 1962). This method was not satisfactory everywhere due to limited exposures and too few identifiable fossils. Where bedding planes were exposed, a quadrat one metre square subdivided into squares $100 \mathrm{~mm}$ on the side was laid on the outcrop. The outlines and positions of the fossils and 


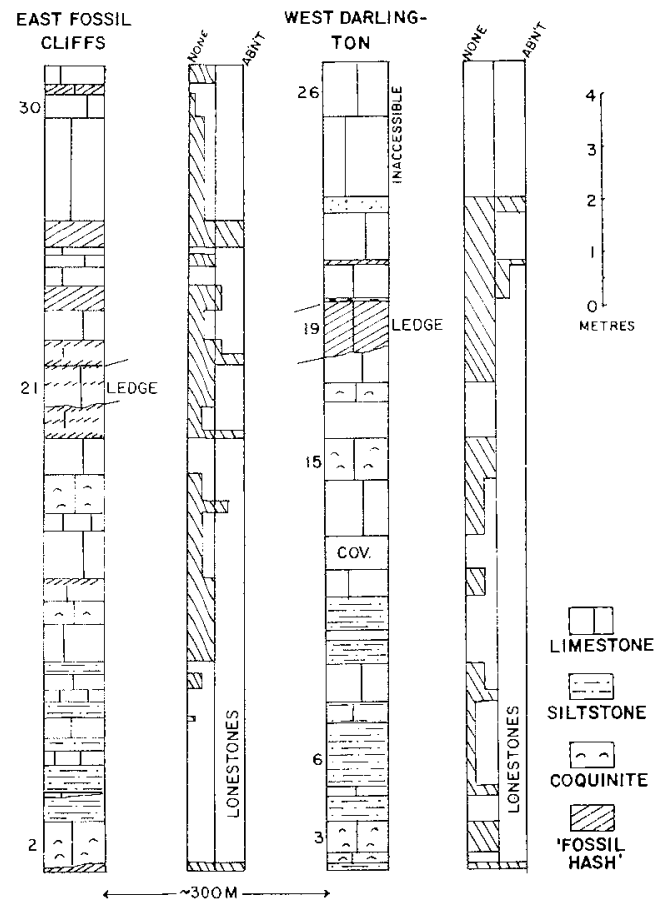

IFIG.2- Columnar sections of Darlington Limestone, Fossil Cliffs, Maria Island. lonestones exposed within the area of the quadrat were drawn to scale on a smaller grid.

Of the basal coquinite (EFC-2) about $50 \%$ of the rock is insoluble in hydrochloric acid. The insoluble residue consists of aggregates of fine sugary silica with larger subangular grains of very fine-grained quartz sand.

Fragments of monaxon sponge (?) spicules are present. Megascopic shells and shell fragments are mainly convex-side up. Using a stretched-1ine a count of shells $0.2 \mathrm{~m}$ above the base of the bed indicates $64 \%$ convex-up; and $0.2 \mathrm{~m}$ below the top $50 \%$ are convex-up. Some are at odd angles to the horizontal.

The metre quadrat was laid on a bedding plane $0.24 \mathrm{~m}$ above the base of Interval EFC-2. About 271 fossils and fragments lay within the area of the quadrat. Of these $61 \%$ were Eurydesma, $11 \%$ spiriferids, $5 \%$ Stenopora, $2 \%$ pectenoids, $18 \%$ fossil fragments, and $2 \%$ small pebbles of crystalline rocks. Minor amounts of fragments of other bryozoans are present.

This same coquinite is present in the West Darlington section (WD-2 and 3). In WD-2 the stretched-line method indicates that the valves of both Eurydesma and pectenoids are $59 \%$ convex-up, and that the bed contains $59 \%$ Eurydesma, $24 \%$ pectenoids and $17 \%$ spiriferids.

The spiriferid calcarenites contain some disarticulated valves of, and numerous fragments of spiriferids such as Trigonotreta stokesi as redefined by C1arke (1979). These beds of calcirudite constitute a "fossil hash" of fragments. A portion of the quadrat was laid on the bedding plane at the top of Interval EFC-22. About 145 fossils and fragments lay within the area of 0.2 square metres. Of these $32 \%$ were spiriferids, $17 \%$ Eurydesma, $7 \%$ encrusting bryozoans, $6 \%$ pebbles of crystalline rocks, and $33 \%$ fossil fragments. On the average the spiriferid calcirudites contain more lonestones than do other types of limestone. Interval EFC-22 contains nine lonestones per $0.2 \mathrm{~m}^{2}$, and about $22.5 \%$ insoluble residue.

In both sections a notable bedding plane lies about $9 \mathrm{~m}$ above the base of the Darlington Limestone. The strata above the break contain no Eurydesma coquinites, but do have more "fossil hash" and more lonestones than the layers below. The strata above the break may represent sedimentation in shallower and somewhat more agitated water.

Experiments show that single valves of Eurydesma tend to orient themselves with the heavy umbo and beak in the direction of the current source. Within the area of the metre quadrat on each of several bedding planes the mean bearing of the umbos of Eurydesma was obtained. This was calculated by addition of unit vectors representing each direction in the plane of the bedding. The bearings and probable current directions are shown in Table 1 .

These somewhat limited data suggest that some currents moved northerly, and to a lesser extent, southerly parallel to the shore that lay along the eastern side of the present Maria Island. The easterly current may represent a current moving along the 
Kenneth G. Bril1, Jnr

bottom from the coast to the east, or a current moving through a Permian inter-island channel (fig. 1). The significance of these current directions is open to question. In any bottom current the last strong motion of the water tends to orient shells in the direction of that current; thus the orientation of Eurydesma may indicate only the final motion of the current rather than the average direction over a long period of time. Banks (1962) postulated that northeasterly longshore currents may have imbricated colonies of Stenopora in this area. This observation is compatible with the data herein.

TABLE 1

ORIENTATION OF THE UMBOS OF VALVES OF EURYDESMA. FOSSIL CLIFFS, MARIA ISLAND.

$\begin{array}{cccc}\text { Bed number } & \begin{array}{c}\text { Number of } \\ \text { specimens }\end{array} & \begin{array}{c}\text { Average } \\ \text { bearing }\end{array} & \begin{array}{c}\text { Current } \\ \text { from }\end{array} \\ \begin{array}{llc}\text { EFC-2 } \\ \text { EFC-2 }\end{array} & \begin{array}{c}30 \text { clearly visible } \\ 24 \text { less clearly visible }\end{array} & 88^{\circ} & \begin{array}{c}\text { East } \\ \text { East }\end{array} \\ \text { EFC-22 } & 5 \text { clearly visible } & 2^{\circ} & \text { North } \\ \text { EFC-30 } & 28 \text { clearly visible } & 0.5^{\circ} & \text { North } \\ \text { WD-16 } & 72 \text { clearly visible } & 180^{\circ} & \text { South } \\ \text { WD-16 } & 13 \text { less clearly visible } & 175^{\circ} & \text { South }\end{array}$

Currents from the west appear to be less common than those from other directions. If the area to the west of the present Maria Island were open water, strong wave action might be expected from the west. If, however, the fetch were impeded by low islands or by ice stranded on shallow barriers, current action from the west might have been greatly reduced. It is postulated that such a barrier existed in Middle Tamarian time trending southward from the area of Mt Connection to the vicinity of Norfolk Bay. It may have coincided with a horst which, in Cainozoic time separated the Midland Graben from the Oyster Bay Graben (Banks 1962, fig.39). If such a barrier were present, it may have consisted of a discontinuous belt of low islands or shallows. Circumstantial evidence for a barrier is found in the paucity of currents from the west at Fossil Cliffs (Table 1), and in the absence of the Bundella Mudstone above the Darlington Limestone in the Maria Island and Cape Surville sections. On the other hand, the presence of lonestones of crystalline rocks derived from western Tasmania (Banks 1962) must be explained. Perhaps these were rafted around the south end of the barrier by southwesterly currents. The shallow water sandstone that overlies the Darlington limestone at Fossil Cliffs may have accumulated in the restricted trough at the close of deposition of the Darlington limestone.

Most Eumydesma and pectenoid shells are disarticulated and many are broken. Heaped together in coquinites they indicate strong current motion. Although thick shel1s have been equated with environments where abrasion is great (Stanley 1970), this is not axiomatic. In bed EFC-2 articulated valves of Eurydesma stand with the hinge upward and parallel to the average current direction. In their position they resemble the growth position of members of the Unionidae; however, such a position for these Eurydesma may be fortuitous.

Disarticulated valves of some Eurydesma bear short vertical tubular borings with diameters in two size ranges, namely 0.25 to $0.30 \mathrm{~mm}$ and 0.016 to $0.026 \mathrm{~mm}$. Some valves are bored both inside and out; however, no borings appear to penetrate completely through the she11. The organisms that did the boring are not known. The diameters of borings of modern annelids are comparable to those in the larger range (Carriker et al. 1969). Borings of blue-green algae are comparable in diameter to those in the smaller range (Budd and Perkins 1980). Borings into the interior surface of the valves indicate that the shells of Eurydesma had been disarticulated for some time before burial. If algae were present, a position in the photic zone is indicated. 
The Darlington Limestone is exposed on the east side of South Maria Island. It consists of about $2 \mathrm{~m}$ of sandy limestone, some beds of which show cross-stratification. M.J. Clarke (oral communication) states that a shoreline lay a short distance west of this exposure on the present South Maria Island.

Satellite (Woody) Island

A Permian stratigraphic section exposed on Satellite (Woody) Island in D'Entrecasteaux Channel was described by Banks, Hale and Yaxley (1955). Here the Golden Valley Group consists of $1.5 \mathrm{~m}$ of Darlington (Eurydesma) Limestone overlain by about $12 \mathrm{~m}$ of Bundella ("Porters Hill") Mudstone.

The Darlington Limestone is a grey, high silt limestone which lacks sorting. Insoluble resiclues range from $35 \%$ to $84 \%$. The metre quadrat was placed on four different bedding planes, and 30 lonestones were noted in a total area of $4 \mathrm{~m}^{2}$, whereas at Fossil Cliffs a total of 14 lonestones were noted within $3.2 \mathrm{~m}^{2}$. Most Satellite Island lonestones are small but one subrounded boulder of porphyry measured $0.41 \times 0.22 \mathrm{~m}$ and an angular boulder of schist measured $0.2 \times 0.1 \mathrm{~m}$. Another notable feature is the thinness of this section in contrast to the Fossil Cliffs section.

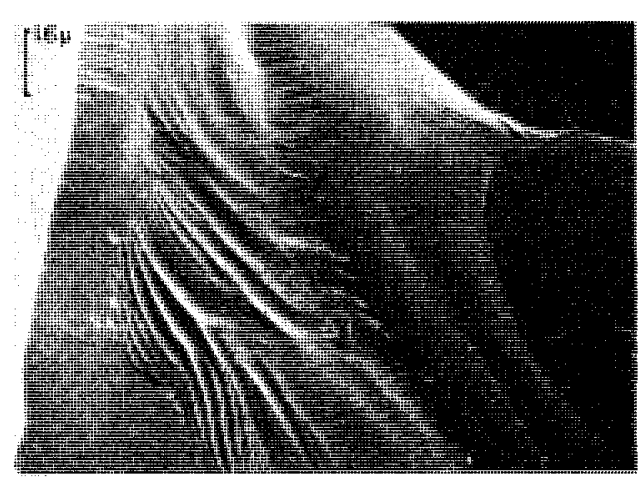

A

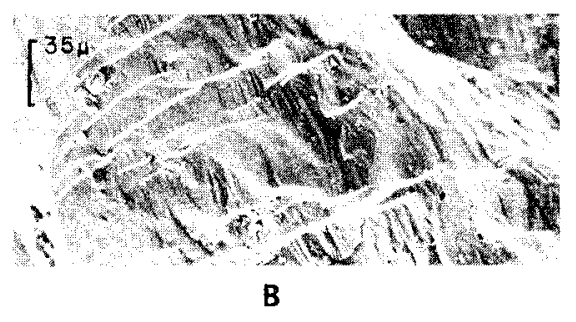

PLATE 1- Scanning Electron Micrographs. A. Quartz grain from basal limestone of Darlington Limestone, Satellite (Woody) Island.

B. Quartz grain from bed WD-19, Darlington Limestone, Fossil Cliffs, Maria Island. 
Kenneth G. Bril1, Jnr

Fine sand-size grains of quartz obtained from insoluble residues were photographed under the Scanning Electron Microscope (p.l. 1). Occasional grains show clean conchoidal fractures similar to the features Krinsley and Doornkamp (1973) attributed to glacial crushing.

Of the 369 fossils and fragments exposed within the metre quadrats, $3 \%$ were Eurydesma, $19 \%$ spiriferids, 38\% ramose Stenopora, $11 \%$ lacy bryozoans, 3\% pectenoid clams, $6 \%$ platy bryozoans, and the remaining $20 \%$ consisted of lonestones and fossil fragments.

Thin sections contain numerous Foraminifera, including Nodosamia, Geinitzina(?) and the encrusting form, Caleitomezla stephensi. Internal moulds of linear uniserial Foraminifera (possibly Nodosamia) are common in the insoluble residues.

Banks et $a z$. (1957) stated that the Darlington Limestone of Satellite (Wooly) Island was deposited in deeper water than that of Maria Island. Several points favour this theory: the paucity of Eurydesma, the thinness of the section, the high percentage of limestone, and the relatively large numbers of Nodosamia. Contrarily, Crespin (1958) quotes J.A. Waters who believes that Calcitome 2 a inhabited warm, moderately shallow waters. The theory that encrusting Foraminifera are indicative of high-energy environments seems not to apply universally to Cazcitomezza.

On two bedding planes there appears to be an alignment of ramose Stenopora. The average bearing of the alignments on the lower bed is $73^{\circ}$, and on the upper, $272^{\circ}$. It is believed that these bearings represent the approximate directions from which the currents came. Banks (1962) found that in the underlying Quamby Group, alignment of zoaria of Stenopora indicated that currents came from the southwest. Glenorchy

Thê Darlington Limestone is overlain by an incomplete section of Bunde1la Mudstone.

Concerning a hole drilled near Glenorchy, Leaman (1976) stated: "Drilling has proved at least $74 \mathrm{~m}$ of this formation [Bundella Mudstone, including Darlington Limestone] at West Glenorchy, and only the upper $27-30 \mathrm{~m}$ is sandy siltstone. The remainder is calcareous with some units of definite but impure limestone".

\section{Glenlusk Road}

The Golden Valley Group is exposed in a cutting on the Glenlusk Road about $4.5 \mathrm{~km}$ west of the Glenorchy borehole. The Darlington Limestone is about $30 \mathrm{~m}$ thick and the Bundella Mudstone about $33 \mathrm{~m}$ thick. As indicated by Sutherland (1964) the section is disturbed by minor faulting and has been somewhat altered by contact metamorphism.

In this section the Darlington Limestone may be divided into three lithologic units. The basa $15 \mathrm{~m}$ of fossiliferous mudstone is unevenly bedded. The middle $15.5 \mathrm{~m}$ contains unevenly bedded mudstone and siltstone with numerous lenses of fossiliferous 1 imestone. The upper $10 \mathrm{~m}$ consists of somewhat altered fossiliferous silty limestone. In the section as a whole, the aggregate thickness of beds of limestone is about $8 \mathrm{~m}$. Due to metamorphism the limestones are only slightly calcareous; however, they are identified by their grey colour, smooth weathered, face and the presence of calcareous fossils.

The limestone lenses, of which five or six are visible in the middle unit, are unusual. Although only two dimensions are visible in the road cutting, the long axes seem to trend northwesterly. In most lenses the beds below are bowed downward; in all the top is horizontal. One lens is composed of fossiliferous siltstone. All contain Eurydesma as well as spiriferids, pectenoids and bryozoans. A line of small lonestones continues beyond the feather-edge of some lenses. Interval 14 is typical, the limestone lens is $3 \mathrm{~m}$ long and a maximum of $0.27 \mathrm{~m}$ thick. It is crowded with disarticulated valves of Eurydesma, $90 \%$ of which are convex-up. The origin of these lenses is unclear. Possibly they represent diastems on which limestone accumulated in pre-existing depressions. On the other hand, they may represent lime mounds or shell banks. If so, the weight of the mound may have caused it to be depressed into the sediment below. Large numbers of the fossils seem 
to be broken and many are fragments, which suggests a high-energy environment. Possibly one or more of these breaks are related to the notable stratigraphic break in the Darlington Limestone at Fossil C1iffs.

Compact silty mudstone beds in the top $2.5 \mathrm{~m}$ of the Darlington Limestone may be altered 1 imestone. Moulds of disarticulated Eurydesma and other fossils are mainly convex-down. This suggests deposition in a low-energy environment, possibly deeper water. Lonestones are smaller and fewer than in nearby sections. Most are associated with beds in the middle unit of the section. Small rounded pebbles of very dark slate or hard shale are common. These may have been derived from Cambrian or Precambrian rocks which today crop out to the southwest. The relative paucity of lonestones in this section suggests that the area may have been distant from land.

The overlying Bunde1la Mudstone is about $32.5 \mathrm{~m}$ thick (Sutherland 1964). It consists of yellowish siltstone in alternate massive and fissile units. The fissile units contain many bryozoans, and some spiriferids, Eurydesma, Strophalosia and other fossils. Lonestone pebbles and boulders are present, especially near the top of the formation. The thickness of the Bundella Mudstone remains fairly constant between the Glenorchy borehole, Glenlusk Road and Maydena Range.

\section{Maydena Range}

The Golden Valley Group is exposed in the Maydena Range (Jago 1972). The Darlington Limestone is exposed along a logging road north of Burma Road on the property of the Australian Newsprint Mills Ltd. The outcrop consists of dark silty limestone and micaceous limy siltstone. Bedding planes are marked by bands of fossils. Jago measured a thickness of $3.7 \mathrm{~m}$ but the present writer observed a thickness of only about $2 \mathrm{~m}$. The section appears to thin toward the south within a short distance. Local variations may account for the discrepancy in the two measurements.

The upper part of the Darlington Limestone is quite fossiliferous. Jago reported that spiriferids form $40 \%$ of the fauna, whereas Eurydesma forms about $5 \%$. The Eurydesma shells are relatively small and more than half are convex-side down. As at the Glenlusk Road, pectenoids are common (15\%). In addition to small rounded white quartz and quartzite pebbles, a notable feature is the presence of fragments of Gordon Limestone (Jago 1972). Today the Gordon Limestone crops out a few kilometres to the west and northwest of this exposure so that the source of some of the detritus may have been close by.

Below the Darlington Limestone is the Satellite Siltstone, the top of which is a noncalcareous grey mudstone with numerous bryozoans and Strophazosia. The Bundella Mudstone overlies the Darlington Limestone and is $32 \mathrm{~m}$ thick (Jago 1972). It consists mainly of sandstone with numerous pebbles. Several beds are quite fossiliferous. The Bundella Mudstone at Maydena Range is coarser in texture than that at Glenlusk Road.

Low energy conditions during deposition of Darlington Limestone are indicated by the convex-down position of Eurydesma valves. The relative coarseness of the Bundella Formation suggests that the area was closer to the shore than was the Glenlusk Road area.

\section{Poatina}

The tripartite nature of the Golden Valley Group along the Western Tiers was reported by McKellar (1957). The Group consists of the Glencoe Formation (Brumby Formation of McKellar) at the base, the Billop Sandstone and the McRae Mudstone (Clarke and Banks 1975). The most complete exposure is along the Poatina Highway, downhill from the village of Poatina (Banks and Clarke 1973). Here the Glencoe Formation consists of about $16 \mathrm{~m}$ of dark, micaceous, poorly laminated, impure shale.

The Darlington Limestone is represented by two limy layers in the Glencoe Formation about $14 \mathrm{~m}$ apart stratigraphically. The lower layer consists of $0.19 \mathrm{~m}$ of very silty "limestone" with about 77\% insoluble residue. It contains numerous spiriferids (60\% of the fauna), Eurydesma, and lacy bryozoans on the bedding planes. Scattered lonestone 
Kenneth G. Brill, Jnr

pebbles are present. The upper limy layer consists of limestone nodules $20 \mathrm{~mm}$ to $0.1 \mathrm{~m}$ thick which contain spiriferids and Strophazosia. The $14 \mathrm{~m}$ of strata between the two limy beds consists mainly of silty shale with spiriferids and lacy bryozoans. Mckellar (1957) who studied both dril1 hole and surface sections reported $1.5 \mathrm{~m}$ of 1 imestone in the Glencoe Formation. Lonestones are common in the limy layers but not in the noncalcareous layers. Possibly warmer water temperatures promoted precipitation of caleium carbonate and at the same time caused the melting of pack ice and calving of glaciers.

The Billop Sandstone consists of about $5.6 \mathrm{~m}$ of grey slightly calcareous sandstone and siltstone. It contains numerous rounded and subrounded pebbles of quartzite. Mckellar (1957) stated that Calcitomezla encrusts the upper surface of many of these pebbles, and that numerous fragments of brachiopods are present. The presence of encrusting Foraminifera suggests relatively slow deposition of sediment.

The McRae Formation was described by McKellar (1957) from both drill hole and surface data. It is $36 \mathrm{~m}$ thick and consists mainly of micaceous, pyritic mudstone with some beds of mar 1 and sandstone. The upper part, which is mainly mudstone, contains bands of pebbles with macrofossils alternating with finer detritus. Banks (1962) suggested that these are turbidity current deposits. The McRae Formation does not contain the Darlington Limestone fauna.

\section{Quamby Brook}

The Quamby Brook locality is about $25 \mathrm{~km}$ northwest of Poatina. It was from this area that Wells (1957) proposed the name Golden valley Group for strata that lie between the Quamby Mudstone and the Liffey Sandstone.

The Glencoe Formation is well exposed in a headwater branch of Quamby Brook above a bridge on the forest road to Liffey. Here the writer measured $22 \mathrm{~m}$ of dark siltstone, some of which emits a foetid odour when fractured. The thickness agrees with that reported by Pike (1973). Several layers contain numerous Eurydesma, pectenoid clams, lacy and ramose bryozoans, and many spiriferids. In a siltstone bed $5.5 \mathrm{~m}$ below the top of the Formation, about $75 \%$ of the shells are Eurydesma, many of which have articulated valves. Disarticulated valves are mainly convex side-down. Northward along the strike this layer contains fossiliferous limestone. A grab sample of this limestone contains $3.4 \%$ insoluble residue. Lonestones of metamorphic rocks are common in the lower part of the Glencoe Formation. They range in size from pebbles to boulders. Core drilling in the Golden valley Group in this area (Clarke 1968) revealed six 1 imestone beds aggregating $0.63 \mathrm{~m}$ in a thickness of $27 \mathrm{~m}$. Clarke reported the presence of Calcitormelza on the inner surfaces of spiriferid valves.

The Glencoe Formation in the Quamby Brook section is more silty and, except for the basal portion, contains fewer lonestones than the Poatina section. This may sugrest that the Quamby Brook area was closer to the source of the detritus, but that the source was not delivering much coarse debris. Some of the sediment seems to have been derived from an island that lay between Frankford and Beaconsfield (Clarke and Banks 1975, p.460). Additional detritus may have come from the west (Banks 1962, fig. 30 d) or from the basement high at Quamby Brook. The foetid odour and the presence of ostracods suggest a restricted environment for the siltstone beds. Disarticulated valves with the convex side-down as well as articulated shells indicate a low-energy environment.

The underlying Quamby Group in this area is thought to have been deposited in deeper water than the Glencoe Formation. It was derived in part from islands to the north (Banks 1962).

The Billop Sandstone consists of about $5 \mathrm{~m}$ of poorly-bedded, medium to coarse-grained sandstone with numerous fossils and many pebbles. The lower layers form a prominent ledge in the creek. The pebbly Billop Formation at Quamby Brook and Poatina, and a pebbly sandstone in the same position at Maydena Range may be a response to an uplift in the area to the west. 
At Quamby Brook the overlying McRae Formation is not well exposed but consists of about $34 \mathrm{~m}$ of mudstone and siltstone.

\section{Lilydale area}

The Golden Valley Group crops out in the Lilydale-Karoola area north of Launceston. Banks (1962, fig.30d) indicated that it is $64 \mathrm{~m}$ thick and that the Darlington Limestone is one metre thick. The best exposure is in the railway cutting between Lilydale and Downie (Longman 1966). Longman reported that the Darlington Formation is $9 \mathrm{~m}$ thick. The actual limestone appears to be considerably thinner. Some of the "limestone" contains as much as $80^{\circ}$ insolubles.

The Darlington Formation consists of dark grey calcareous shale and very silty limestone which contain Eumdesma, small ramose Stenopora, Strophalosia, and abundant Calcitormezza. Some of the latter encrust bryozoans. Disarticulated valves of Eurydesma are oriented convex-up and some are vertical. Lacy bryozoans are common in the shaly beds. The limy beds are overlain by dark grey claystone and silty clay shale which are sparingly fossiliferous. The closest lithologic counterpart of the Lilydale locality is the Poatina section. This may mean that the environment on the two sides of the basin was similar at this time. Fewer lonestones were observed in the Lilydale section than in any other. Those present consist of pebbles of dark quartz, quartzite and other metamorphic rocks.

A limited section occurs near Karoola in an abandoned quarry on the Karoola-Bangor road (Marshall 1969), about $7 \mathrm{~km}$ west of the Lilydale exposure. The Darlington Limestone equivalent is about one metre thick (Longman 1966). The macrofossils are smaller than those at Lilydale and ostracods are present.

The shore of the "Golden Valley sea" lay a few kilometres east of Lilydale (Banks 1962). The Darlington Limestone thins rapidly against this ancient shore (Longman 1966). An island west of the Tamar Estuary (Clarke and Banks 1975, fig. 33.4) formed the western shore.

If Calcitomelza is characteristic of warmer waters, it may indicate that this area, which was close to shore represents shallow water with a minimum of floating ice. The latter is suggested by the paucity of lonestones. Occasional grains of glauconite in the limestones of the Lilydale section also suggest warmer waters with slow deposition.

On the north coast of Tasmania stratigraphic equivalents of the Darlington Limestone occur in portions of the Masseys Creek Group (Gee and Legge 1974). The writer examined three exposures: Middle Arm Creek, West Arm of Tamar (Anderson Creek), and Port Sorel1.

\section{Middle Arm}

This exposure occurs about $40 \mathrm{~m}$ north of the old lime kiln on the east side of the mouth of the Middle Arm of the Tamar Estuary (Gee and Legge 1974). It consists of about one metre of silty limestone overlain by at least $0.4 \mathrm{~m}$ of conglomerate. The limestone contains about $12 \%$ insolubles. Macrofossils and fragments present on $0.15 \mathrm{~m}^{2}$ of vertical face consist of $50 \%$ unidentified fossil fragments, $21 \%$ pebbles and boulders, $20 \%$

Eumydesma, 5\% spiriferids, 3\% platy bryozoans, plus many Caleitomezza. The shells are mainly single valves, convex-up. From the topmost layer of limestone, 23 lonestones were collected from one linear metre. Table 2 shows their nature and possible source. The calcareous fragments may have been derived from Ordovician strata which today are exposed $5 \mathrm{~km}$ to the west near Beaconsficld. Devonian granite is exposed today 30 to $40 \mathrm{~km}$ to the east. The greatest number of lonestones seem to have been derived from the Mathinna Formation or other Early Palaeozoic rocks which today crop out $6 \mathrm{~km}$ to the west and in a large area about $12 \mathrm{~km}$ to the east. Either of these areas may have been the source of the fragments; however, the relatively large number at Middle Arm and the relatively smali number at Lilydale and Karoola suggest that the Frankford-Beaconsfield island may have been the more important source. 
Kenneth G. Brill, unr

TABLE 2

TYPES OF PEBBLES

taken along a stretched line one metre long on the outcrop of Interval 3. Middle Arm of Tamar section.

Number of specimens
Rock type

rey quartz schist, $60 \mathrm{~mm}$ diameter

Grey quartz schist, fine-grained

Dark micaceous quartz schist

Grey quartzite

Mica phyllite

Grey altered rock, green mineral, quartz, clay

Quartz sandstone, poorly sorted

Weathered chert nodule with calcareous centre, $20 \times 50 \mathrm{~mm}$

Colourless quartz

Grey quartz

Grey quartzite

Layered quartzite

Weathered yellow quartzose rock

Weathered yellow claystone

Silty grey limestone with micro-veinlet

Phylite

Muscovite schist

Fine-grained banded quartzite

Dark grey granite (quartz, light coloured feldspar)
Possible sources

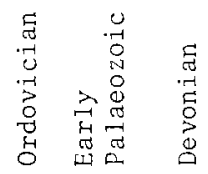

$x$

$x$

$x$

$\mathrm{x}$

$x$

$\mathrm{x}$

Total 23 fragments

A conglomerate above the limestone consists of a calcareous matrix with pebbles and boulders the 1ithology of which is similar to the lonestones in the limestone below.

In a road cut a short distance south of this exposure, brown siltstone with lenses of limestone containing many Strophazosia lies at a higher stratigraphic position than the conglomerate.

In the Middle Arm section the Darlington Limestone is characterized by poor bedding and numerous she11s that are at odd angles to the bedding. This suggests sha1low water conditions of deposition.

West Arm of Tamar

This section lies along the lower end of Andersons Creek and near the mouth of Masseys Creek. Here the Masseys Creek Group has a thickness of $290 \mathrm{~m}$ (Gee and Legge 1974). The section is not completely exposed but supplementary data have been obtained from holes drilled by the Tasmanian Geological Survey and correlated by M.J. C1arke (in Gee and Legge 1974). The Darlingtón Limestone fauna (Faunizone 2) is present in a grey fossiliferous mudstone which is visible at the mouth of Masseys Creek at low tide (M.J. Clarke, 
oral communication). The writer was guided to this locality by M.R. Banks. The mudstone lies $120 \mathrm{~m}$ stratigraphically below the Liffey Sandstone and some $10 \mathrm{~m}$ below a band of large calcareous concretions. The position of the fauna may be obtained by comparing the diagram in Clarke and Farmer (1976, p.96) with that of Gee and Legge (1974, fig.15). The latter stated that the mudstone contains Deltopecten, Eurydesma, Grantonia, Pseudosyrinx and Strophazosia.

\section{Port Sorel 1}

An extensive stratigraphic section of the Masseys Creek Group occurs in the estuary at Port Sore11. It is exposed above low tide level on the west side of "The Tongue". The section is interrupted by a fault (Gee and Legge 1974). These authors reported that here the total thickness of the Masseys Creek Group is a minimum of $350 \mathrm{~m}$ and a maximum of $520 \mathrm{~m}$, assuming no duplication by faulting. The portion of the section north of the fault, herein called the Lower Port Sore 11 section, is $56 \mathrm{~m}$ thick between the lowest exposed limestone and the highest. It consists of silty limestone interbedded with very fine-grained sandstone and mudstone. Many lonestones are present, most of which are in the limestone beds. Many layers contair fossils and fossil fragments. Spiriferids and bryozoans are common. The largest lonestones observed in the Golden Valley-Masseys Creek Groups are in the Port Sorell section.

The portion of the section south of the fault, herein called the Upper Port Sorell section is about $12.6 \mathrm{~m}$ thick. It consists of two limestone units with sandstone and claystone between. The upper 1 imestone bed is $1.7 \mathrm{~m}$ thick and contains about $30 \%$ insolubles. The weathered surface has a "sandpaper" appearance. A quadrat $0.21 \mathrm{~m}^{2}$ in area was placed on a bedding plane of this limestone. Of 100 specimens within the area of the quadrate $40 \%$ were lonestones, $29 \%$ ramose bryozoans, $20 \%$ spiriferids, $4 \%$ Eurydesma, $4 \%$ Strophalosia, $1 \%$ lacy bryozoans, and $1 \%$ fossil fragments. Near the middle of this same limestone bed there is a coquinite of Eurydesma, with some spiriferids and pectenoids which lie both convex-up and convex-down. The base of this coquinite is a mass of Stenopora and shell fragments which rest on the claystone beneath.

It is thought that the limestone of the Upper Port Sorell section is equivalent to the Darlington Limestone.

As indicated by the cross-section in Clarke and Banks (1975) the Liffey Sandstone overlies increasingly older beds westward in northern Tasmania so that the Darlington Limestone is not found in this area.

Reports of Palaeozoic strata at depth in the Bass Basin and Gippsland Basin (McPhee 1975) lead to the speculation that the Permian marine basin may have extended northward and northeastward into these areas. The Bassian Rise may have been a barrier but might have only partially restricted migration of marine faunas to and from the southern New South Wales basins. Two facts suggest that the Permian strata may have extended into the Bass Basin: the thick sequence of strata in the West Arm and Port Sore11 sections; and the presence of relatively pure limestone beds in the Masseys Creek Group in both of these sections.

\section{Western Tasmania}

In the vicinity of Lake St Clair the equivalent of the Golden Valley Group has been reported in a portion of the Wallace River Group (Banks 1962). On the upper Alma River, near Goulds Sugarloaf, a stratigraphic section (Gulline 1965) shows $97.5 \mathrm{~m}$ of Wallace River Group which includes $3 \mathrm{~m}$ of 1 imestone and some $79 \mathrm{~m}$ of fossiliferous mudstone with pebbles. The limestone is equivalent to the Darlington Limestone.

In the area of Cradle Mountain the Golden Valley Group is often missing. Terrestrial conglolerates of Permian age 1 ie immediately to the south (Banks 1962). The source of some of the Golden valley sediments was in this upland. 
On the west coast possible Golden Valley equivalents have been reported from Point Hibbs (Banks and Ahmad 1962). About 142 m of cyclic sediments consist mainly of conglom erate and siltstone. The pebbly beds contain fossils such as Eurydesma, Keeneia and Stenopora, In a fossiliferous siltstone in one cycle a bed of fossiliferous limestone $0.46 \mathrm{~m}$ thick is present. Banks and Ahmad (1962) suggested that this may be the Darlington Limestone equivalent. About $100 \mathrm{~m}$ below the limestone, cross-bedded sandstone indicates currents from $225^{\circ}$ and ripple marks trend $340^{\circ}$. These strata may be equivalent to the Quamby Group.

A stratigraphic succession on Mt Sedgwick, north of Queenstown, contains a bed of limestorie $0.5 \mathrm{~m}$ thick. Banks. and Ahmad (1962) suggest that it may correlate with the Darlington Limestone.

An east-west trending seaway across Tasmania in Golden Valley time is postulated (fig. 1). This separates the northwest upland from the inferred southwest upland. The presence of the seaway is suggested by the distribution of Darlington Limestone and related strata at Point Hibbs, Mt Sedgwick, and the Lake St Clair area. In addition, discontinuous deposits of other Permian strata occur in this area (Banks 1962). If Permian strata originally covered the area, uplift of the horst in western Tasmania (Banks 1962, fig. 39) may have raised the strata to elevations which permitted erosion to remove much of the section.

\section{PALAEOENVIRONMENT}

The Late Palaeozoic glaciation in Tasmania has been known for many years. Palaeomagnetic studies by Embleton (1973) placed the Permian South Pole in the present Great Australian Bight. Among those who have published palaeogeographic maps to show the position of Tasmania with respect to Gondwana glaciation are Lacey (1975), E11iot (1975) and Crowell (1978).

During the Tamarian time in Tasmania there were at least three, and probably four, sources of sediment (fig. 1): (i) the northeast and east, including portions of Maria Island, (ii) the Cradle Mountain and northwest upland (Banks 1962, fig.30D), (iii) the Beaconsfield-Frankford island (Clarke and Banks 1975), and (iv) a postulated area in southwestern Tasmania (fig. 1). Although no tillite of Tamarian age has been identified on these uplands, probably at times all the larger areas bore glaciers from which icebergs and pack ice were derived. Clarke (1968) postulated the presence of a dry-base glacier near Quamby Brook, and Banks (1962) postulated piedmont glaciers in the uplands, both postulates applying to pre-Darlington Limestone time. Clarke and Banks (1975, p.460) illustrated conglomerates near former shorelines.

\section{Lonestones}

Conglomeratic layers are present in the Golden Valley and Masseys Creek Groups and should not be confused with lonestones. Fine detritus as well as lonestones, which range in size from pebbles to boulders nearly a metre in length, are scattered through the Darlington Limestone. Some lonestones are in bands; however, most are isolated and embedded in the underlying strata. The latter are thought to have been dropped into soft sediment from floating ice. Clearly striated or faceted lonestones were not observed by the writer but faceted pebbles have been reported by Banks (1962). Many lonestones are subrounded to subangular which suggests that at one time they were transported by water. These could have been frozen into pack ice along former beaches or bars.

The sources of some of the lonestones have been referred to by Banks (1962). Fragments from the Gordon Limestone, Mathinna Formation and Devonian granite are distinctive. Future studies may link the numerous metamorphic rock fragments with their sources.

In the Darlington Limestone, lonestones seem to be most abundant in the limy layers, and at Fossil Cliffs lonestones are more abundant in the spiriferid calcirudites 
("fossil hash") than in the coquinites or silty layers. A possible explanation for this phenomenon may be that the high energy which fragmented the shells and concentrated them, may have caused the pack ice to break up and loose the rock fragments. Mil1iman (1973), however, stated that the $\mathrm{CO}_{2}$ content of water is increased by turbulence, especially in polar seas, which would tend to decrease the amount of limy precipitation.

Quartz grains from several localities were examined under the scanning electron microscope. Some grains showed conchoidal fracture which is characteristic of glacial crushing (p1,1).

\section{Water temperature}

The Darlington Limestone contains about 30 genera of macrofossils, but the bulk of the fauna consists of a few genera. In many limy beds the valves of Eurydesma comprise more than half of the fossils. Spiriferid brachiopods are abundant and, in the silty layers, fragments of ramose and lacy bryozoans are abundant. Numerous individuals of relatively few taxa could be explained by the fact that the environmental conditions departed from the optimum for most taxa concerned (Thienemann's Rule). In this case the conditions could have been low water temperature, low salinity or both. Cold water is suggested not only by the lonestones but by the presence of a foramol fauna (Lees 1975). Lees stated that in shelf associations a mollusc-bryozoan benthonic foraminiferal fauna can occur at low temperatures, particularly where the salinity is below that of normal seawater.

Today much of the carbonate sediment in high latitudes is in the form of shell debris (Chave 1967). This is not inconsistent with the large accumulations of shell debris in portions of the Darlington Limestone. Foster (1974) indicated that brachiopods in the present Ross Sea (Antarctica) show an inversed relationship between density of individuals and diversity of types. The largest population and maximum shell sizes occur along the front of the ice shelf. Although the first part of this analogy applies to the Darlington Limestone, evidence for the latter part is not obvious.

Oxygen isotope data obtained from Eurydesma and Trigonotreta shells from southeastern Tasmania indicate cold water ("glacially derived") conditions for these specimens (Green et al. 1979).

The foraminifera yield conflicting evidence as to temperature. Calcitomelza is believed by some (Crespin 1947, p.29) to represent warm water conditions whereas the genus Hippocrepine Zla is found today in both the Arctic and Antarctic oceans. Both genera occur in the Darlington Limestone (Banks 1962). Although Calcitomelza is present in many parts of the Tasmanian Basin it seems to be most abundant in the Lilydale-Karoola and Middle Arm sections. If Calcitornezza is indeed characteristic of warm shallow water, the portion of the Basin north of Launceston may have been somewhat warmer than the less restricted parts of the Basin. Encrusting foraminifera commonly are associated with high-energy environments.

\section{Hydraulic energy}

Energy in the form of waves and currents expresses itself in the sorting of sediments and in various sedimentary structures. The Darlington Limestone shows very poor sorting at most localities and few sedimentary structures. The carbonate is mixed with detritus of various sizes. Some of the best sorting appears to be $i$ the coquinites in the Fossil Cliffs. Here large numbers of Eurydesma, pectenoids and spiriferids are heaped together with a minimum of matrix. It is apparent that these layers represent death assemblages developed by current and wave action. The absence of juveniles lerids credence to this theory. It is postulated that these Eumdesma coquinites were broad shell ridges in relatively shallow water where shells were amassed by wave action. Pectenoid clams may have been derived from lagoons shoreward from the ridges. A modern analogue may be found on barrier beaches where great numbers of the heavy valves of the clam Mercenaria are heaped up by storm waves. 
Kenneth G. Bri11, Jnr

At Fossil Cliffs coquinites formed at successively higher stratigraphic levels as deposition continued; however, above the erosional(?) break (fig. 2, Int.2l, EFC) no coquinite occurs. At this time conditions became less favourable for Eurydesma, but spiriferids became more abundant. Possibly these conditions were due to a shallowing of the water. Wave action churned the botton and spiriferid calcirudite ("fossil hash") formed. Pack ice breaking up in shallow water provided numerous lonestones.

Directional properties

Indications of current direction are rare in the Darlington Limestone. The orientation of umbos of single valves of Eurydesma at Fossil Cliffs indicate northerly, southerly and easterly currents but such orientation may not indicate prolonged current activity in any one direction. Small scale cross-bedding is present on the east side of South Maria Island. Imbrication of Stenopora zoaria at Fossil Cliffs suggests northeasterly currents (Banks 1962). The alignment of ramose bryozoans at Satellite (Woody) Island indicates northeasterly and southwesterly currents. Cross-bedding and ripple marks in pre-Darlington Limestone strata at Point Hibbs indicate southwesterly currents (Banks and Ahmad 1962).

Nearly all of these directional properties indicate a general southwest-northeast motion of waters. If, as appears to be the case, the Tasmania Basin was open to the south and restricted to the north, these alignments are not surprising. The palaeogeographic map of the Early Permian by Crowel1 (1978) shows ocean currents from a direction which is now south of Tasmania.

Nearly all the localities where evidence of current action has been found lie on the outer edges of the Tasmanian Basin. Possibly strong current and wave action was impeded in the central part by the shape of the basin as well as by islands, bars and, at times, by pack ice. A possible distribution of bottom energy in the basin during Darlington Limestone time might resemble the cross-section (fig. 3). The typical shelf-sea pattern of sedimentation is complicated by the presence of detritus dropped from floating ice.

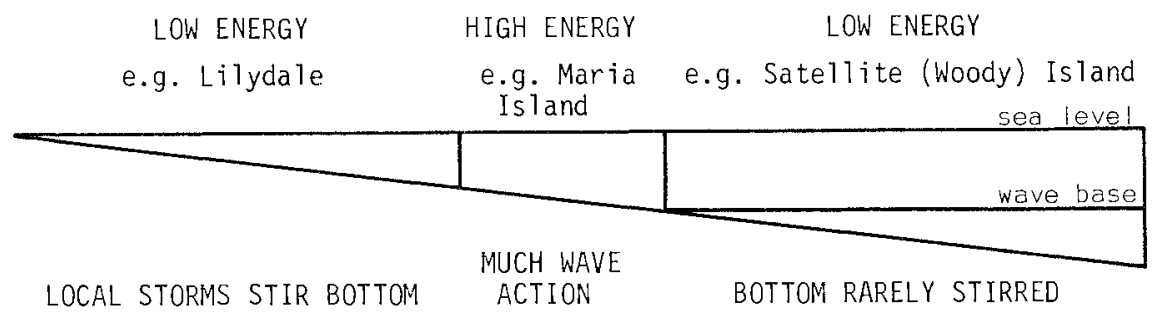

FIG.3-Diagrammatic representation of hydraulic energy conditions in Darlington Limestone time.

\section{Depth of water}

Banks (1962) stated that the grain size of the Golden Valley Group decreases toward the west and northwest which suggests an easterly source and a shallower sea to the east. The presence of numerous bryozoans in sections such as Poatina and Quamby Brook may indicate relatively deep water. Studies of modern bryozoans off South Australia (Wass et al. 1970) indicate that reteporiform (lacy) types are found in quiet water at depths greater than $115 \mathrm{~m}$ and that viniculariform (ramose) types are common at depths 1 ess than $55 \mathrm{~m}$ where current and wave action are present. Elias (1936) believed that bryozoans ranged from 23 to $50 \mathrm{~m}$ in depth in the Early Permian seas of Kansas. 
Although thickness of shells of bivalves has been correlated with shallow water and strong abrasion (Stanley 1970) this is not universal.

Some of the minute borings in the valves of Eurydesma at Fossil Cliffs are in a size range comparable to borings of blue-green algae. If algae were present, the shells, at some time, must have been in the photic zone.

Cyclic sedimentation

Cyclic and rhythmic sedimentation has been noted at several stratigraphic levels in the Permian of Tasmania. Cycles in the Berriedale Limestone and Grange Formation were noted by Brill (1956). The Berriedale cycles were restudied by Rao (1979) who attributed them to glacial fluctuations.

In the Darlington Limestone at Fossil Cliffs eleven cycles were described by Banks (1957). Banks and Hale (1957) noted the altemation of fissile and non-fissile siltstone in the Bunde11a Mudstone at Hobart. Sutherland (1964) noted similar alternations in the Bunde1la Mudstone along Collinsvale Road. Larger cycles were mentioned by McKe11ar (1957) in the Golden Valley Group at Poatina. Four thick cycles in the Golden Valley Group were found at Point Hibbs by Banks and Ahmad (1962).

Most explanations of the cycles are based on waxing and waning of glaciers in Gondwana. Contraxily, Crowell (1978) stated that, although there may be more than one cause, the cycles are probably related to sea-floor spreading which caused eustatic changes in sea level. An interesting theory involving wet-base and dry-base glaciers to explain the marine sediments of the Permian of Tasmania has been proposed by Carey and Ahmad (1961). They postulated that rhythmic marine sedimentation could be produced near the end of a dry-base glacier.

The present writer believes that glaciation may be regarded as the primary cause of these cycles with tectonic movements providing local effects. Until more precise marker beds within the Golden Valley Group are found, it will be difficult to determine 1 ateral gradations within the unit and to make long distance correlations.

\section{REFERENCES}

Banks, M.R., 1957: The stratigraphy of Tasmanian limestones. Geol. Surv. Tasm. Min. Res., 10: 39-85. , 1962: in Spry, A. and Banks, M.R. (Eds): THE GEOLOGY OF TASMANIA. J. geol. Soc. Aust., 9 (2): 107-354.

, 1973: General Geology, in LAKE COUNTRY OF TASMANIA. Royal Society of Tasmania: $25-34$. - Hale, G.E.A. and Yaxley, M.L., 1955: The Permian rocks of woody Island. Pap. Proc. R. Soc. Tasm., 89: 218-229. and Hale, G.E.A., 1957: A type section of the Permian System in the Hobart area. Pap. Proc. R. Soc. Tasm., 91: 41-64. and Ahmad, N., 1962: The Permian System in western Tasmania. Pap. Proc. R. Soc. Tasm., 96: 1-18.

and Clarke, M.J., 1973: Parmeener Supergroup. Field trip No.1, Upper Carboniferous to Triassic Rocks in southeastern Australia. 3rd Intemat. Gondivana Sympos., Canberra: 23-46.

Brill, K.G., Jr, 1956: Cyclic sedimentation in the Permian system of Tasmania. Pap. Proc. R. Soc. Tasm., 90: 131-140.

Budd, D.A. and Perkins, R.D., 1980: Bathymetric zonation and paleontological significance of microborings in Puerto Rico shelf and slope sediments. J. sed. Petrol., 50: 881909.

Carey, S.W. and Ahmad, N., 1961: Glacial marine sedimentation. Proc. 1st Intemat. Sympos. on Arctic Geology, 2: 865-894.

Carriker, M.R., Smith, E.H. and Wilce, R.T., 1969: Penetration of calcium carbonate substrates by lower plants and invertebrates. Am. Zoologist, 9 (Ed.2): 747-751. 
Kenneth G. Brill, Jnr

Chave, K.E., 1967: Recent carbonate sediments: an unconventional view. J. geol. Educ., 15: $200-204$.

Clarke, M.J., 1968: A reappraisal of a Lower Permian type section, Golden Valley, Tasmania. Tasm. Dept Mines, Geol. Sum. Rec. 7: $32 \mathrm{pp.}$

, 1979: The Tasmanian Permian spiriferid brachiopods Tmigonotreta stokesi. Koenig, 1825, Grantonia hobartensis Brown, 1953, and Spirifer tasmanienses Morris, 1845. J. Paleont., 53: 197-207.

and Banks, M.R., 1975: The stratigraphy of the Lower (Permo-Carboniferous) parts of the Parmeener Supergroup, Tasmania. In Campbell, K.S.W. (Ed.): GONDWANA GEOLOGY. Aust, Nat. Univ. Press: 453-467.

and Farmer, N., 1976: Biostratigraphic nomenclature for Late Palaeozoic rocks in Tasmania. Pap. Proc. R. Soc. Tasm., 110: 91-109.

Crespin, I., 1958: Permian foraminifera of Australia. Bur. Min. Res. BuZ2. 48 : 203 pp. Crowell, J.C., 1978: Gondwana glaciation, cyclothems, continental positioning and climatic change. Am. J. Sci., 278: 1345-1372.

Elliot, D.H., 1975: Gondwana basins of Antarctica. In Campbell, K.S.W. (Ed.): GONDWANA GEOLOGY. Aust. Nat. Univ. Press: 493-536.

Elias, M.K., 1936: Depth of deposition of the Big Blue sediments in Kansas. Geol. Soc. Am. Bul2., 48: 403-432.

Embleton, B.J.J., 1973: Palaeolatitude of Australia through Phanerozoic time. J. geol. Soc. Aust., 19: 475-482.

Foster, M.W., 1974: Recent Antarctic and Subantarctic brachiopods. Antarc. Res. Ser. 21, Am. Geoph. Un. : 173 pp.

Gee, R.D. and Legge, P.J., 1974: Geological Atlas 1 Mile series, Zone 7, Sheet 30, Beaconsfield. Geol. Surv. Tasm.

Green, D.C., Clarke, M.J. and Rao, C.P., 1979: Permian palaeotemperature data from Tasmania and quest for a modern analogue in Antarctica. (Abst.) J. geol. Soc. Aust., 26: 283 .

Gulline, A.B., 1965: Geological Atlas 1 Mile Series, K55-10-59 st Clair. Geol. Surv. Tasm.

Jago, J.B., 1972: Geology of the Maydena Range. Pap. Proc. R. Soc. Tasm., 106: 45-56.

Johnson, R.G., 1962: Mode of formation of marine fossil assemblages of the Pleistocene Millerton Formation. Geol. Soc. Am. Bull. 73: 113-130.

Krinsley, D.H. and Doornkamp, J.C., 1973: ATLAS OF QUARTZ SAND SURFACE TEXTURES. Cambridge Press: 91 pp.

Iacey, W.S., 1975: Some problems of mixed floras in the Permian of Gondwanaland. Campbell, K.S.W. (Ed.): GONDWANA GEOLOGY. Aust. Nat. Univ. Press: 125-147.

Leaman, D.E., 1976: Geological Atlas 1:50 000 ser., Zone 7, Sheet 82, Hobart. Geol. Surv. Tasm.

Lees, A., 1975: Possible influence of salinity and temperature in modern shelf carbonate sedimentation. Marine Geol., 19: 159-198.

Longman, M.I., 1966: Geological Atlas 1 Mile Series, K55-7-39, Launceston, Geol. Surv. Tasm.

Marshall, B., 1969: Geological Atlas 1 Mile Series, Zone 7, Sheet 31, Pipers River. Geol. Sum. Tasm.

Mckellar, J.B.A., 1957: Geology of a portion of the Western Tiers. Rec. Q. Vict. Mus., $7: 1-13$.

McPhee, I., 1975: Petroleum resources of offshore southeast Australia. A.P.E.A. J., $15: 55-59$.

Milliman, J.D., 1974: MARINE CARBONATES, RECENT SEDIMENTARY CARBONATES, PT.1. Springer-Verlag, N.Y.: 375 Pp.

Pike, G.P., 1973: Geological Atlas 1 Mile Series, Zone 7, sheet 46, Quamby. Geol. Surv. Tasm.

Rao, C.P., 1979: Dropstones, an evidence of glacio-marine carbonate sedimentation. Search, 10: 279-281.

Stanley, S.M., 1970: Relation of shell form to life habits of Bivalvia (Mollusca), modern Atlantic Ocean. Geol. Soc. Am. Mem. 125: 281 pp.

Sutherland, F.I., 1964: The geology of the Collinsvale area. Pap. Proc. R. Soc. Tasm., $119-133$. 
Wass, R.F., Conolly, J.R. and MacIntyre, R.J., 1970: Bryozoan carbonate sand contiruous along southern Australia. Marine Geol., 9: 63-73.

Wells, A.T., 1957: Geology of the Deloraine-Golden Valley area, Tasmania. Rec. Q. vict. Mus., 8: $32 \mathrm{pp}$. 